\title{
Association between the Components of Metabolic Syndrome and Total Bilirubin at the Health Care Check Up in Korean Men and Women: Based on Adults Except for Diabetes and Hypertension
}

Kyung-A Shin

Department of Clinical Laboratory Science, Shinsung University, Dangjin, Korea

\section{당뇨와 고혈압 환자를 제외한 건강검진을 실시한 한국 성인남녀의 대사증후군 구성요소와 총 빌리루빈간의 관련성}

\author{
신경아
}

신성대학교 임상병리과

\begin{abstract}
Bilirubin has an anti-inflammatory effect as an endogenous antioxidant and has been reported to be inversely correlated with hypertension, diabetes, metabolic syndrome, and insulin resistance. On the other hand, there is a lack of research evaluating the association between bilirubin and metabolic syndrome compared to liver-specific indicators. This study examined the association between the total bilirubin and metabolic syndrome prevalence in Korean adults who underwent health screening compared to ALT and GGT. This cross sectional study included 22,568 adult males and females aged 20 years or older who underwent a health examination at the General Hospital of Gyeonggi Province from March 2015 to February 2018. Metabolic syndrome was diagnosed based on the American Heart Association/National Heart, Lung, and Blood Institute (AHA/NHLBI) guidelines. In both genders, the metabolic syndrome diagnosed group had higher liver enzymes, and the total bilirubin and direct bilirubin were lower than those without the metabolic syndrome risk factors. The serum total bilirubin showed a weak inverse correlation with abdominal obesity ( $r=$ -0.066 vs $r=-0.055$ ) and triglyceride ( $r=-0.127$ vs $r=-0.136$ ) in both males and females, which is weaker than ALT and GGT The data were statistically significant. In addition, total bilirubin as well as ALT and GGT in both men and women were not predictors of the likelihood of developing metabolic syndrome.
\end{abstract}

Key words: ALT, GGT, Metabolic syndrome, Total bilirubin

This is an Open Access article distributed under the terms of the Creative Commons Attribution Non-Commercial License (http://creativecommons.org/licenses/by-nc/4.0) which permits unrestricted non-commercial use, distribution, and reproduction in any medium, provided the original work is properly cited.

Copyright @ 2018 The Korean Society for Clinical Laboratory Science. All rights reserved.
Corresponding author: Kyung-A Shin Department of Clinical Laboratory Science, Shinsung University, 1 Daehak-ro, Jeongmi-myeon, Dangjin 31801, Korea Tel: 82-41-350-1408 Fax: 82-41-350-1355

E-mail:mobitz2@hanmail.net

Received: April 23, 2018 Revised $1^{\text {st: }}$ May 10, 2018 Revised $2^{\text {nd. }}$ : May 17,2018 Accepted: May 17, 2018

\section{서 론}

대사증후군은 복부비만, 인슐린 저항성, 고혈압 및 이상지질 혈증이 함께 동반되는 질환으로 심혈관계 질환 및 제 2형 당뇨
병의 위험 증가와 관련이 있다[1]. 대사증후군의 정확한 병태생 리학적 특징은 여전히 불분명하다. 인슐린 저항성, 아디포카인, 산화적 스트레스, 만성 염증 및 내피기능 장애와같은 복잡한 병 태생리학적 기전이 대사증후군을 유발하는 원인으로 제시되 
며, 이는 산화 스트레스와 밀접하게 관련되어 있다[1, 2].

한편, 빌리루빈은 헴 이화작용의 최종 대사산물이며, 잠재적 인 항산화제, 항염증제 및 세포를 보호하는 역할을 한다[3]. 혈 청 빌리루빈이 낮으면 경동맥 내막 두께가 증가하고 혈관 확장 장애가 나타나는 반면, 혈청 빌리루빈이 높으면 말초동맥 질환 및 뇌졸중과 같은 동맥경화성 폐색질환을 낮추는 것으로 보고 된다[4-6]. 특히 높은 빌리루빈 수치는 아디포넥틴을 증가시켜 대사증후군 발병 핵심인자인 인슐린 저항성을 개선시키는 것으 로 알려져 있다[7]. 이를 뒷받침하는 몇몇의 횡단면 연구는 빌리 루빈과 대사증후군간의 역상관 관계가 있음을 보고하였다 $[8$, 9]. 그러나 혈청 빌리루빈과 대사증후군의 연관성에 대해서는 논란의 여지가 있다. 일본 코호트 연구는 총 빌리루빈과 대사증 후군 사이의 유의한 관련성을 발견하지 못하였으며, 빌리루빈 은 대사증후군 위험인자가 아니라고 보고하였다[10]. 더욱이 대사증후군에서 혈청 빌리루빈의 감소는 대사증후군에 의한 것 이 아니라 대사증후군과 밀접한 산화 스트레스에 의해 유발된 다고 제시하였다[10]. 이러한 관점에서 Perera 등[11]은 태국 성인에서 간 특이적 효소의 상승이 대사증후군 위험과 관련이 있음을 보고하였다. Shin [12]의 연구에서도 대사적으로 건강 한 비만 남성을 대상으로 간 효소인 알라닌 아미노 전이효소 (alanine aminotransferase, ALT) 및 감마 글루타밀 전이효소 (gamma-glutamyl transferase, GGT)가 대사적 이상을 예측 할 수 있는 지표임을 제시하고 있어 간 특이적 효소와 더불어 혈 청 빌리루빈과 대사증후군간의 관련성을 평가하는 연구가 필요 하다. 이에 본 연구에서 건강검진을 실시한 한국 성인남녀를 대 상으로 성별에 따른 간 특이적 지표인 ALT, GGT와 비교하여 총 빌리루빈과 대사증후군 유병률 사이의 관련성을 조사하고자 하 였다.

\section{대상 및 방법}

\section{1. 연구 대상}

연구 대상자는 2015년 3월부터 2018년 2월까지 경기도 소 재 종합병원에서 건강검진을 실시한 20세 이상 성인남녀 23,356 명 이었다. 전체 대상자 중 혈액 검사상 B형 간염 표재성 항원(HBsAg) 양성자, C형 간염 항체(anti-HCV) 양성자, 만성 간질환의 과거력이 있는 자, 고혈압, 당뇨병으로 약물치료 중 인 대상자, 해당 연구자료에 결측치가 있는 경우에 해당하는 788 명을 제외한 최종 연구대상자는 22,568 명 이었다. 대사증후군 이 동반된 고혈압, 당뇨병 환자를 제외하고자 고혈압과 당뇨병 으로 약물치료 중인 대상자를 제외하였다. 연구 대상자의 과거
병력이나 약물치료에 관한 자료는 건강검진 공통 문진표에 의 해 조사하였으며, 이 연구는 경기도 소재 종합병원 기관생명윤 리위원회(institutional review board, IRB)의 심의를 거쳐 승 인 후 연구를 진행하였다(IRB No: SP-2018-14-012-007).

\section{2. 연구방법}

\section{1) 신체계측 및 혈압측정}

연구 대상자들의 신체계측 중 신장 및 체중은 Inbody 720 (Biospace Co., Seoul, Korea) 체성분 분석기로 측정하였고, 체 질량지수(body mass index, BMI)는 체중 $(\mathrm{kg})$ 을 신장 $(\mathrm{m})$ 의 제 곱 $\left(\mathrm{kg} / \mathrm{m}^{2}\right)$ 으로 나누어 계산하였다. 허리둘레는 늑골 최하단부 와장골능선 사이의 중간 부위를 줄자로 측정하였다. 보정된 아 네로이드 혈압계(Medisave UK Ltd., Weymouth, UK)를 이용 하여 수축기 혈압과 이완기 혈압을 측정하였으며, 5 분간 안정상 태에서 2회 측정하여 평균값을 결과로 제시하였다.

\section{2) 대사증후군 진단기준 및 혈액분석}

대사증후군의 진단은 American Heart Association/ National Heart, Lung, and Blood Institute (AHA/NHLBI)지 침의 5 가지 기준 중 3 가지 이상 만족하는 경우 대사증후군으로 판정하였으며, 복부비만 기준은 World Health Organization (WHO)의 서태평양 지부에서 제시한 아시아-태평양 지역의 기 준으로 (1)허리둘레; 남성 $90 \mathrm{~cm}$ 이상, 여성 $80 \mathrm{~cm}$ 이상 (2) 공복 혈당(fasting blood sugar); $100 \mathrm{mg} / \mathrm{dL}$ 이상 (3중성지방 (triglyceride, TG); $150 \mathrm{mg} / \mathrm{dL}$ 이상 (4) 고밀도 지단백 콜레스 테롤(high density lipoprotein cholesterol, HDL-C); 남성 40 $\mathrm{mg} / \mathrm{dL}$ 미만, 여성 $50 \mathrm{mg} / \mathrm{dL}$ 미만 (5)수축기 혈압; $130 \mathrm{mmHg}$ 이상 이거나 이완기 혈압; $85 \mathrm{mmHg}$ 이상인 경우 를 적용하였 다[13, 14]. 혈액분석은 검사 당일 오전에 8시간 이상 공복상태 를 확인한 후상완 정중주정맥(median cubital vein)에서 채혈 하여 분석하였다. 생화학적 분석항목 중 총콜레스테롤, 중성지 방, $\mathrm{HDL}$-콜레스테롤, 저밀도 지단백 콜레스테롤(low density lipoprotein cholesterol, LDL-C), 공복혈당, 요산(uric acid, $\mathrm{U} . \mathrm{A})$, 총 빌리루빈(total bilirubin, T-Bil), 직접 빌리루빈 (direct bilirubin, D-Bil), 아스파테이트 아미노 전이효소 (aspartate aminotransferase, AST), 알라닌 아미노 전이효소 (alanine aminotransferase, ALT), 감마 글루타밀기 전이효소 (gamma-glutamyl transferase, GGT)는 TBA-200FR NEO (Toshiba, Tokyo, Japan)를 이용하여 측정하였다. 당화혈색소 (hemoglobin A1c, HbA1c)는 EDTA (ethylene diamine tetra acetic acid, EDTA) 전혈 검체로 고속액체크로마토그래피법 
(high performance liquid chromatography, HPLC)의 원리 에 의해 Variant II (Bio Rad, CA, USA) 장비로 분석하였다. 전기 화학발광 면역분석법(electrochemiluminescence immunoassay)의 원리를 이용한 Roche Modular Analytics E170 (Roche, Mannheim, Germany)으로 인슐린을 검사하였다.

\section{3. 통계분석}

이 연구결과는 평균土표준편차 또는 \%로 제시하였다. 남녀 모두에서 대사증후군 유무에 따른 연구 대상자의 인체측정 및 생화학적 지표의 차이는 독립표본 $t$-test (independent sample $t$-test)로 비교하였다. 총 빌리루빈, ALT, GGT 4분위수에 따른 대사증후군 및 대사증후군 구성요소의 발생빈도 차이는 카이제 곱검정(chi-square test)으로 확인하였다. 또한 연령을 보정한 후 총 빌리루빈, ALT, GGT와 대사증후군 구성요소 사이의 상관 관계(correlation coefficient)를 분석하였다. 대사증후군 구성 요소의 개수에 따른 총 빌리루빈, ALT, GGT의 차이는 일원변량 분석(one way analysis of variance, one-way ANOVA)으로 확인하였으며, 사후검증은 Scheffe 방법을 적용하였다. 총 빌
리루빈, ALT, GGT 사분위수에 따른 대사증후군 발생 가능성을 예측하기 위해 연령을 보정한 후 이분형 로지스틱 회귀분석 (binominal logistic regression)을 적용하였다. 모든 통계분석 은 IBM SPSS Statistics 24.0 (IBM, NY, USA)을 이용하여 처리 하였으며, $P<0.05$ 이면 통계적으로 유의한 것으로 평가하였다.

\section{결 과}

\section{1. 대사증후군 유무에 따른 남녀 대상자의 임상적 특성}

남녀 대상자의 대사증후군 유무에 따른 임상적 특징은 Table 1 과 같다. 남성은 대사증후군 유무에 따라 신장과 LDL-콜레스 테롤을 제외한 모든 변인에서 집단간 차이를 보였다(모두 $P<$ 0.001). 특히 ALT, GGT는 대사증후군 진단군에서 높았으나, 총 빌리루빈과 직접 빌리루빈은 대사증후군 진단군에서 낮게 나타 났다(각각 $P<0.001$ ). 여성은 대사증후군 유무에 따라 모두 측 정변인에서 차이를 보였으며(모두 $P<0.001), \mathrm{ALT}, \mathrm{GGT}$ 는 대 사증후군 진단군에서 높았으며(각각 $P<0.001)$, 총 빌리루빈 $(P=0.001)$ 과 직접 빌리루빈 $(P<0.001)$ 은 대사증후군 진단군

Table 1. Clinical characteristics of men and women according to metabolic syndrome status

\begin{tabular}{|c|c|c|c|c|c|c|}
\hline \multirow[b]{2}{*}{ Variables } & \multicolumn{2}{|c|}{ Men $(\mathrm{N}=13,773)$} & \multirow[b]{2}{*}{$P$-value } & \multicolumn{2}{|c|}{ Women $(\mathrm{N}=8,795)$} & \multirow[b]{2}{*}{$P$-value } \\
\hline & $\begin{array}{c}\text { MetS } \\
(\mathrm{N}=1,599)\end{array}$ & $\begin{array}{l}\text { Non-MetS } \\
(\mathrm{N}=12,174)\end{array}$ & & $\begin{array}{c}\text { MetS } \\
(\mathrm{N}=601)\end{array}$ & $\begin{array}{l}\text { Non-MetS } \\
(\mathrm{N}=8,194)\end{array}$ & \\
\hline Age (years) & $48.87 \pm 10.99$ & $45.29 \pm 10.89$ & $<0.001$ & $56.36 \pm 11.62$ & $43.99 \pm 11.10$ & $<0.001$ \\
\hline Height $(\mathrm{cm})$ & $171.51 \pm 6.40$ & $171.44 \pm 6.37$ & 0.691 & $155.72 \pm 6.00$ & $158.99 \pm 5.86$ & $<0.001$ \\
\hline Weight (kg) & $81.42 \pm 11.00$ & $71.40 \pm 9.60$ & $<0.001$ & $65.55 \pm 9.23$ & $56.04 \pm 7.59$ & $<0.001$ \\
\hline $\mathrm{BMI}\left(\mathrm{kg} / \mathrm{m}^{2}\right)$ & $27.63 \pm 2.92$ & $24.26 \pm 2.75$ & $<0.001$ & $27.01 \pm 3.04$ & $22.20 \pm 3.00$ & $<0.001$ \\
\hline$W C(\mathrm{~cm})$ & $92.20 \pm 6.67$ & $82.59 \pm 7.06$ & $<0.001$ & $84.89 \pm 6.58$ & $72.02 \pm 7.37$ & $<0.001$ \\
\hline $\mathrm{SBP}(\mathrm{mmHg})$ & $123.55 \pm 14.71$ & $111.28 \pm 12.08$ & $<0.001$ & $122.42 \pm 17.34$ & $103.11 \pm 13.03$ & $<0.001$ \\
\hline DBP (mmHg) & $80.46 \pm 10.55$ & $71.98 \pm 9.36$ & $<0.001$ & $77.46 \pm 10.95$ & $65.87 \pm 9.23$ & $<0.001$ \\
\hline $\mathrm{TC}(\mathrm{mg} / \mathrm{dL})$ & $199.98 \pm 36.88$ & $194.69 \pm 33.63$ & $<0.001$ & $203.95 \pm 37.17$ & $188.23 \pm 33.04$ & $<0.001$ \\
\hline $\mathrm{TG}(\mathrm{mg} / \mathrm{dL})$ & $241.68 \pm 117.48$ & $131.91 \pm 83.41$ & $<0.001$ & $189.11 \pm 91.77$ & $83.09 \pm 44.89$ & $<0.001$ \\
\hline $\mathrm{HDL}-\mathrm{C}(\mathrm{mg} / \mathrm{dL})$ & $43.70 \pm 10.38$ & $53.09 \pm 11.82$ & $<0.001$ & $46.52 \pm 9.69$ & $63.55 \pm 13.05$ & $<0.001$ \\
\hline LDL-C (mg/dL) & $123.36 \pm 33.31$ & $121.97 \pm 30.28$ & 0.113 & $130.75 \pm 33.48$ & $111.37 \pm 29.94$ & $<0.001$ \\
\hline Glucose (mg/dL) & $110.19 \pm 30.87$ & $90.03 \pm 16.98$ & $<0.001$ & $106.35 \pm 28.56$ & $85.56 \pm 11.48$ & $<0.001$ \\
\hline $\mathrm{HbA} 1 \mathrm{c}(\%)$ & $6.24 \pm 1.15$ & $6.24 \pm 1.15$ & $<0.001$ & $6.28 \pm 1.10$ & $5.45 \pm 0.47$ & $<0.001$ \\
\hline Insulin $(\mu \mathrm{U} / \mathrm{mL})$ & $7.77 \pm 3.98$ & $4.80 \pm 2.94$ & $<0.001$ & $7.45 \pm 3.99$ & $4.23 \pm 2.48$ & $<0.001$ \\
\hline Uric acid (mg/dL) & $6.33 \pm 1.46$ & $6.01 \pm 1.25$ & $<0.001$ & $4.82 \pm 1.16$ & $4.16 \pm 0.92$ & $<0.001$ \\
\hline hs-CRP (mg/dL) & $0.21 \pm 0.49$ & $0.16 \pm 0.46$ & $<0.001$ & $0.20 \pm 0.25$ & $0.11 \pm 0.31$ & $<0.001$ \\
\hline AST (IU/L) & $34.48 \pm 20.48$ & $28.20 \pm 25.09$ & $<0.001$ & $28.22 \pm 20.74$ & $22.33 \pm 12.66$ & $<0.001$ \\
\hline ALT (IU/L) & $42.96 \pm 28.19$ & $29.48 \pm 29.23$ & $<0.001$ & $27.82 \pm 30.13$ & $17.13 \pm 13.38$ & $<0.001$ \\
\hline GGT (IU/L) & $77.25 \pm 74.35$ & $48.07 \pm 57.61$ & $<0.001$ & $32.15 \pm 48.86$ & $19.83 \pm 18.89$ & $<0.001$ \\
\hline T-Bil (mg/dL) & $1.03 \pm 0.38$ & $1.12 \pm 0.46$ & $<0.001$ & $0.83 \pm 0.32$ & $0.88 \pm 0.33$ & 0.001 \\
\hline D-Bil (mg/dL) & $0.18 \pm 0.07$ & $0.20 \pm 0.08$ & $<0.001$ & $0.14 \pm 0.05$ & $0.15 \pm 0.06$ & $<0.001$ \\
\hline
\end{tabular}

Values are presented as means \pm standard deviations.

Abbreviations: MetS, metabolic syndrome; BMI, body mass index; WC, waist circumference; SBP, systolic blood pressure; DBP, diastolic blood pressure; TC, total cholesterol; TG, triglyceride; HDL-C, high density lipoprotein cholesterol; LDL-C, low density lipoprotein cholesterol; HbA1c, hemoglobin A1c; hs-CRP, high sensitivity C-reactive protein; AST, aspartate aminotransferase; ALT, alanine aminotransferase; GGT, gamma-glutamyl transferase; T-Bil, total bilirubin; D-Bil, direct bilirubin. 
에서 유의하게 낮았다.

\section{2. 총 빌리루빈, ALT, GGT 사분위수에 따른 대사증후군 및 대사증후군 구성요소의 발생빈도}

남성의 총 빌리루빈, ALT, GGT 사분위수에 따른 대사증후군 및 대사증후군 구성요소의 발생빈도는 Table 2 와 같다. 남성은 총 빌리루빈, ALT, GGT 사분위수에 따라 대사증후군 및 5 가지 대사증후군 구성요소의 발생빈도에 차이가 없었다. 여성의 경 우 총 빌리루빈, GGT 사분위수에 따른 대사증후군 및 대사증후 군 구성요소의 발생빈도는 차이가 없었다. 그러나 ALT 사분위 수에 따른 대사증후군 $(P=0.005)$ 과 높은 혈압 $(P=0.002)$ 의 발생 빈도는 차이가 있었으며, 2 사분위수에서 가장 높은 빈도를 보였 다(Table 3).

\section{3. 총 빌리루빈, ALT, GGT와 대사증후군 구성요소간의 상관관계}

연령을 보정한 후 총 빌리루빈, ALT, GGT와 대사증후군 구 성요소간의 상관성을 확인한 결과 Table 4와 같다. 남성에서 총 빌리루빈은 허리둘레 $(r=-0.066)$, 총콜레스테롤 $(r=-0.026)$, 중성지방 $(r=-0.127)$, 공복혈당 $(r=-0.045)$ 과 유의한 역상관 관
계를 보였으며, $\mathrm{HDL}$-콜레스테롤 $(r=0.087)$ 과는 정적 상관관계 를 나타냈다. ALT는 HDL-콜레스테롤을 제외한 모든 대사증후 군 구성요소와 정적인 상관관계를 보였으며, $\mathrm{HDL}$-콜레스테롤 과는 역상관 관계를 나타냈다. 또한 GGT는 남성에서 모든 대사 증후군 구성요소와 유의한 정적 상관관계를 보였다. 여성의 경 우 총 빌리루빈은 허리둘레 $(r=-0.055)$, 중성지방 $(r=-0.136)$ 과 유의한 역상관 관계를 보였으며, $\mathrm{HDL}-$ 콜레스테롤 $(r=0.103)$ 과는 정적 상관관계를 보였다. $\mathrm{ALT}$ 는 총콜레스테롤, $\mathrm{HDL}$-콜레 스테롤과 역상관 관계를 보였으며, 그 외의 대사증후군 구성요 소와는 정적인 상관관계를 나타냈다. GGT는 $\mathrm{HDL}$-콜레스테롤 을 제외한 모든 대사증후군 구성요소와 유의한 정적 상관성을 보였다(Table 4).

\section{4. 대사증후군 구성요소의 개수에 따른 총 빌리루빈, ALT, GGT의 차이}

대사증후군 구성요소의 개수에 따른 총 빌리루빈의 차이를 비교한 결과 남성에서는 대사증후군 구성요소가 없는 군보다 대사증후군 구성요소가 1 개, 2개, 3 개, 4 개 이상인 군에서 총 빌 리루빈치가 낮았으며, 대사증후군 구성요소가 1 개인 군보다 대 사증후군 구성요소가 2 개, 3 개, 4 개 이상인 군의 총 빌리루빈이

Table 2. Characteristics of study subjects based on serum bilirubin quartile categories men

\begin{tabular}{|c|c|c|c|c|c|}
\hline T-Bil (mg/dL) & $\begin{array}{l}\text { 1st quartile } \\
(<0.82)\end{array}$ & $\begin{array}{l}\text { 2nd quartile } \\
(0.82 \sim 1.01)\end{array}$ & $\begin{array}{l}\text { 3rd quartile } \\
(1.02 \sim 1.29)\end{array}$ & $\begin{array}{l}\text { 4th quartile } \\
\quad(\geq 1.30)\end{array}$ & $P$-value \\
\hline MetS $(N=1,599)$ & $382(11.1)$ & $408(11.6)$ & $414(11.8)$ & $395(11.9)$ & 0.756 \\
\hline Abdominal obesity $(\mathrm{N}=2,868)$ & $684(19.9)$ & $776(22.1)$ & $716(20.3)$ & $692(20.9)$ & 0.126 \\
\hline High fasting glucose $(\mathrm{N}=2,458)$ & $594(17.3)$ & $625(17.8)$ & $624(17.7)$ & $615(18.6)$ & 0.581 \\
\hline Low HDL-C $(N=1,819)$ & $433(12.6)$ & $476(13.6)$ & $478(13.6)$ & $432(13.1)$ & 0.593 \\
\hline High TG $(N=4,890)$ & $1,179(34.4)$ & $1,264(36.0)$ & $1,254(35.6)$ & $1,193(36.1)$ & 0.418 \\
\hline High $\mathrm{BP}(\mathrm{N}=2,350)$ & $596(17.4)$ & $590(16.8)$ & $600(17.0)$ & $564(17.0)$ & 0.943 \\
\hline ALT (IU/L) & $(<18)$ & $(18 \sim 24)$ & $(25 \sim 35)$ & $(\geq 36)$ & $P$-value \\
\hline MetS $(N=1,599)$ & $365(11.0)$ & $427(12.8)$ & $410(11.4)$ & $397(11.2)$ & 0.090 \\
\hline Abdominal obesity $(\mathrm{N}=2,868)$ & $678(20.5)$ & $738(22.1)$ & $733(20.5)$ & $719(20.3)$ & 0.195 \\
\hline High fasting glucose $(\mathrm{N}=2,458)$ & $596(18.0)$ & $593(17.8)$ & $647(18.1)$ & $622(17.5)$ & 0.936 \\
\hline Low HDL-C $(N=1,819)$ & $432(13.1)$ & $479(14.4)$ & $478(13.3)$ & $430(12.1)$ & 0.052 \\
\hline High TG $(N=4,890)$ & $1,178(35.6)$ & $1,235(37.1)$ & $1,254(35.0)$ & $1,223(34.5)$ & 0.136 \\
\hline High $\mathrm{BP}(\mathrm{N}=2,350)$ & $567(17.1)$ & $544(16.3)$ & $623(17.4)$ & $616(17.4)$ & 0.614 \\
\hline GGT (IU/L) & $(<23)$ & $(23 \sim 34)$ & $(35 \sim 57)$ & $(\geq 58)$ & $P$-value \\
\hline MetS $(N=1,599)$ & $343(11.5)$ & $465(11.9)$ & $406(11.8)$ & $385(11.2)$ & 0.770 \\
\hline Abdominal obesity $(\mathrm{N}=2,868)$ & $648(21.7)$ & $797(20.4)$ & $705(20.5)$ & $718(20.8)$ & 0.567 \\
\hline High fasting glucose $(\mathrm{N}=2,458)$ & $539(18.1)$ & $688(17.6)$ & $632(18.4)$ & $599(17.4)$ & 0.692 \\
\hline Low $\operatorname{HDL}-\mathrm{C}(\mathrm{N}=1,819)$ & $401(13.4)$ & $505(12.9)$ & $488(14.2)$ & $425(12.3)$ & 0.128 \\
\hline High TG $(N=4,890)$ & $1,098(36.8)$ & $1,370(35.0)$ & $1,226(35.7)$ & $1,196(34.7)$ & 0.332 \\
\hline High $\mathrm{BP}(\mathrm{N}=2,350)$ & $486(16.3)$ & $697(17.8)$ & $571(16.6)$ & $596(17.3)$ & 0.316 \\
\hline
\end{tabular}

Data are expressed as number of subjects (\%).

Abbreviations: T-Bil, total bilirubin; MetS, metabolic syndrome; HDL-C, high density lipoprotein cholesterol; TG, triglyceride; BP, blood pressure; ALT, alanine aminotransferase; GGT, gamma-glutamyl transferase. 
Table 3. Characteristics of study subjects based on serum bilirubin quartile categories women

\begin{tabular}{|c|c|c|c|c|c|}
\hline T-Bil (mg/dL) & $\begin{array}{c}1^{\text {st }} \text { quartile } \\
(<0.64)\end{array}$ & $\begin{array}{l}2^{\text {nd }} \text { quartile } \\
(0.65 \sim 0.79)\end{array}$ & $\begin{array}{l}3^{\text {rd }} \text { quartile } \\
(0.80 \sim 1.00)\end{array}$ & $\begin{array}{c}4^{\text {th }} \text { quartile } \\
(\geq 1.01)\end{array}$ & $P$-value \\
\hline MetS $(N=601)$ & $123(6.3)$ & $141(6.6)$ & $148(6.4)$ & $189(7.9)$ & 0.120 \\
\hline Abdominal obesity $(\mathrm{N}=1,701)$ & $355(18.1)$ & $430(20.2)$ & $424(18.4)$ & $492(20.5)$ & 0.103 \\
\hline High fasting glucose $(\mathrm{N}=739)$ & $165(8.4)$ & $172(8.1)$ & $181(7.9)$ & $221(9.2)$ & 0.357 \\
\hline Low HDL-C $(\mathrm{N}=1,594)$ & $352(18.0)$ & $389(18.2)$ & $386(16.8)$ & $467(19.5)$ & 0.120 \\
\hline High TG $(\mathrm{N}=994)$ & $213(10.9)$ & $231(10.8)$ & $243(10.6)$ & $307(12.8)$ & 0.058 \\
\hline High BP $(\mathrm{N}=746)$ & $183(9.3)$ & $162(7.6)$ & $175(7.6)$ & $226(9.4)$ & 0.029 \\
\hline ALT (IU/L) & $(<11)$ & $(11 \sim 13)$ & $(14 \sim 19)$ & $(\geq 20)$ & $P$-value \\
\hline MetS $(N=601)$ & $126(6.3)$ & $182(8.5)$ & $152(6.6)$ & $141(6.0)$ & 0.005 \\
\hline Abdominal obesity $(\mathrm{N}=1,701)$ & $379(19.1)$ & $452(21.1)$ & $450(19.5)$ & $420(17.8)$ & 0.053 \\
\hline High fasting glucose $(\mathrm{N}=739)$ & $159(8.0)$ & $207(9.6)$ & $188(8.1)$ & $185(7.9)$ & 0.120 \\
\hline Low HDL-C $(\mathrm{N}=1,594)$ & $359(18.1)$ & $402(18.7)$ & $429(18.6)$ & $4.4(17.1)$ & 0.494 \\
\hline High TG $(N=994)$ & $205(10.3)$ & $252(11.7)$ & $280(12.1)$ & $257(10.9)$ & 0.232 \\
\hline High BP $(N=746)$ & $178(9.0)$ & $216(10.1)$ & $162(7.0)$ & $190(8.1)$ & 0.002 \\
\hline GGT (IU/L) & $(<12)$ & $(12 \sim 15)$ & $(16 \sim 21)$ & $(\geq 22)$ & $P$-value \\
\hline MetS $(N=601)$ & $127(7.2)$ & $172(6.8)$ & $166(7.5)$ & $136(5.9)$ & 0.189 \\
\hline Abdominal obesity $(\mathrm{N}=1,701)$ & $341(19.4)$ & $503(19.8)$ & $420(19.0)$ & $437(19.1)$ & 0.872 \\
\hline High fasting glucose $(\mathrm{N}=739)$ & $157(8.9)$ & $216(8.5)$ & $181(8.2)$ & $185(8.1)$ & 0.766 \\
\hline Low HDL-C $(N=1,594)$ & $305(17.4)$ & $457(18.0)$ & $431(19.4)$ & $401(17.5)$ & 0.276 \\
\hline High TG $(N=994)$ & $194(11.0)$ & $301(11.9)$ & $258(11.6)$ & $241(10.5)$ & 0.469 \\
\hline High BP $(\mathrm{N}=746)$ & $159(9.0)$ & $237(9.3)$ & $173(7.8)$ & $177(7.7)$ & 0.106 \\
\hline
\end{tabular}

Data are expressed as number of subjects (\%).

Abbreviations: See Table 2.

Table 4. Age adjusted correlations between bilirubin and metabolic components in men and women

\begin{tabular}{|c|c|c|c|c|c|c|}
\hline \multirow{2}{*}{ Parameters } & \multicolumn{3}{|c|}{ Men } & \multicolumn{3}{|c|}{ Women } \\
\hline & T-Bil & ALT & GGT & T-Bil & ALT & GGT \\
\hline$W C(\mathrm{~cm})$ & $-0.066^{\star \star}$ & $0.237^{\star \star}$ & $0.174^{\star \star}$ & $-0.055^{\star \star}$ & $0.183^{\star \star}$ & $0.150^{\star \star}$ \\
\hline $\mathrm{SBP}(\mathrm{mmHg})$ & -0.002 & $0.088^{\star \star}$ & $0.118^{\star \star}$ & -0.004 & $0.070^{\star \star}$ & $0.073^{\star \star}$ \\
\hline DBP (mmHg) & 0.013 & $0.088^{\star \star}$ & $0.119^{\star *}$ & 0.001 & $0.064^{\star \star}$ & $0.073^{\star \star}$ \\
\hline $\mathrm{TC}(\mathrm{mg} / \mathrm{dL})$ & $-0.026^{\star}$ & $0.110^{\star \star}$ & $0.148^{\star \star}$ & 0.019 & $-0.079^{\star \star}$ & $0.101^{\text {** }}$ \\
\hline TG (mg/dL) & $-0.127^{\star \star}$ & $0.173^{\star \star}$ & $0.267^{* *}$ & $-0.136^{\star \star}$ & $0.105^{\star *}$ & $0.170^{\star \star}$ \\
\hline $\mathrm{HDL}-\mathrm{C}(\mathrm{mg} / \mathrm{dL})$ & $0.087^{\star \star}$ & $-0.126^{\star \star}$ & $0.042^{\star \star}$ & $0.103^{\star \star}$ & $-0.079^{* \star}$ & -0.017 \\
\hline LDL-C (mg/dL) & -0.015 & $0.100^{\star \star}$ & $0.046^{\star *}$ & 0.002 & $0.062^{\star \star}$ & $0.068^{\star *}$ \\
\hline Glucose (mg/dL) & $-0.045^{\star \star}$ & $0.101^{\star *}$ & $0.185^{\star \star}$ & -0.012 & $0.110^{\star \star}$ & $0.137^{\star \star}$ \\
\hline
\end{tabular}

${ }^{*} P<0.05$.

$\star * P<0.001$

Abbreviations: See Table 1.

낮게 나타났다 $(P<0.001)$. 여성의 경우 대사증후군 구성요소가 없는 군보다 대사증후군 구성요소가 1개, 2개, 3 개인 군에서 총 빌리루빈이 낮았다 $(P<0.001)$ (Figure 1). 대사증후군 구성요 소의 개수에 따른 ALT와 GGT의 차이를 비교한 결과 남성의 경 우 ALT와 GGT 모두 대사증후군 구성요소가 없는 군보다 대사 증후군 구성요소가 1 개, 2 개, 3 개, 4 개 이상인 군의 ALT와 GGT 가 높았으며, 대사증후군 구성요소가 1 개인 군보다 대사증후군 구성요소가 2개, 3 개, 4 개 이상인 군의 ALT와 GGT가 높았다. 또한 대사증후군 구성요소가 3 개와 4 개 이상인 군은 대사증후
군 구성요소가 2 개인 군보다 $\mathrm{ALT}$ 와 GGT가 높게 나타났다 $(P<$ 0.001) (Figure 2,3). 여성의 경우 대사증후군 구성요소의 개수 가 증가할수록 비례하여 ALT가 상승하였다 $(P<0.001)$ (Figure 2). 여성에서 GGT는 대사증후군 구성요소가 없는 군보다 대사 증후군 구성요소가 1 개, 2 개, 3 개, 4 개 이상인 군에서 높게 나타 났으며, 대사증후군 구성요소가 1 개인 군보다 대사증후군 구성 요소가 2개, 3 개, 4 개 이상인 군의 GGT가 높았다. 또한 대사증 후군 구성요소가 4 개 이상인 군은 대사증후군 구성요소가 2개, 3 개인 군보다 GGT가 높게 나타났다 $(P<0.001)$ (Figure 3). 


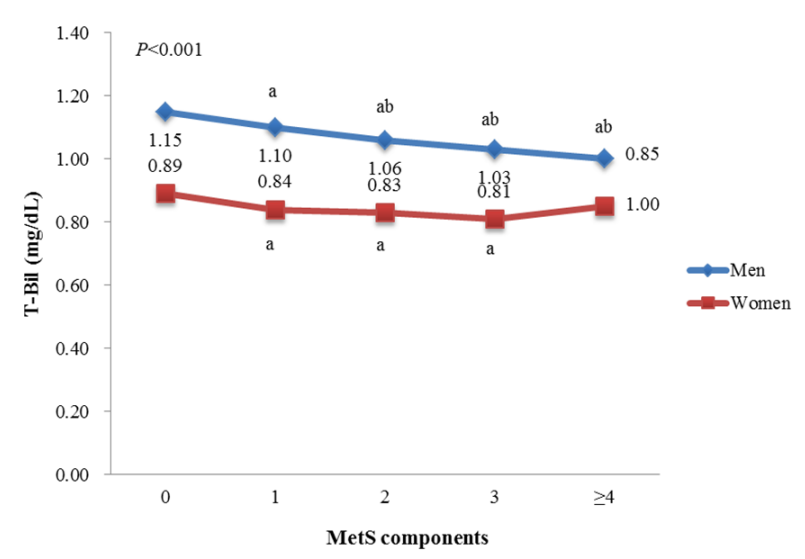

Figure 1. Differences in T-Bil according to the components of metabolic syndrome. a: significantly different from the without MetS components, b: significantly different from one components of the MetS, c: significantly different from two components of the MetS, d: significantly different from three components of the MetS. Abbreviations: See Table 2.

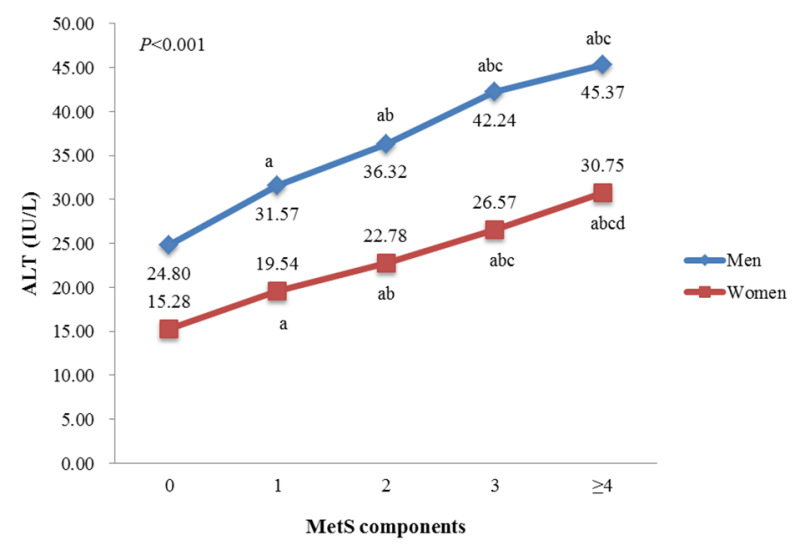

Figure 2. Differences in ALT according to the components of metabolic syndrome. a: significantly different from the without MetS components, $b$ : significantly different from one components of the MetS, c: significantly different from two components of the MetS, d: significantly different from three components of the MetS. Abbreviations: See Table 2.

\section{5. 총 빌리루빈, ALT, GGT 사분위수에 따른 대사증후군 발생 가능성}

남성의 경우 총 빌리루빈, ALT, GGT 사분위수에 따른 대사 증후군 발생 가능성은 보정하지 않은 경우와 연령을 보정한 경 우 모두에서 의미 있는 차이가 없었다(Table 5). 여성의 경우 총 빌리루빈 사분위수에 따른 대사증후군 발생 가능성은 보정하지 않은 경우 1 사분위수보다 2 사분위수에서 대사증후군 발생 가 능성이 0.79 배 낮았으나, 연령을 보정한 경우 의미 있는 차이가 없었다. 또한 ALT 사분위수에 따른 대사증후군 발생 가능성은 보정하지 않은 경우 1 사분위수보다 3 사분위수에서 대사증후군 발생 가능성이 1.04 배 높았으며, 연령을 보정한 경우 1 사분위 수보다 3 사분위수에서 대사증후군 발생 가능성이 1.38 배 높았

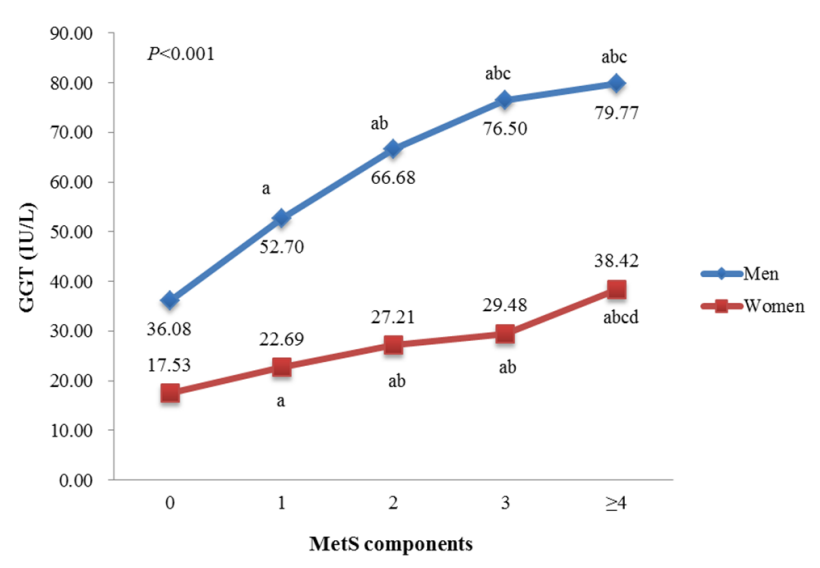

Figure 3. Differences in GGT according to the components of metabolic syndrome. a: significantly different from the without MetS components, b: significantly different from one components of the MetS, c: significantly different from two components of the MetS, d: significantly different from three components of the MetS. Abbreviations: See Table 2.

다. 그러나 GGT 사분위수에 따른 대사증후군 발생 가능성은 보 정하지 않은 경우와 연령을 보정한 경우 모두에서 의미 있는 차 이가 없었다(Table 5).

\section{고 찰}

건강검진을 실시한 한국 성인남녀를 대상으로 한 이 횡단면 연구는 ALT와 GGT의 간 기능 지표와 비교하여 총 빌리루빈과 대사증후군간의 관련성을 확인하였다. 성인남녀 모두에서 혈 청 총 빌리루빈은 대사증후군 구성요소와 약한 역상관 관계를 보였으며, 이는 ALT와 GGT보다 약한 관련성을 나타냈다. 또한 남녀 모두에서 ALT와 GGT뿐만 아니라 총 빌리루빈은 대사증 후군 발생 가능성을 예측하는 지표는 아닌 것으로 나타났다.

최근 연구에 따르면 산화 스트레스가 인슐린 저항성 및 대사 증후군을 특징짓는데 중요한 역할을 한다고 밝혀졌다[1]. 빌리 루빈은 내인성 항산화제로서 항염작용이 있으며, 지질 및 지질 단백질의 산화를 억제하고 활성산소를 제거하며 산화 스트레스 를 방지하는 것으로 알려져 있다[3, 15]. 그러므로 빌리루빈은 대사증후군 발병 기전에 영향을 미칠 수 있다. 여러 연구에서 빌 리루빈은 고혈압, 당뇨병, 대사증후군 및 인슐린 저항성과 역상 관 관계가 있음을 보고하였다[5, 6, 16]. Wu 등[17]은 혈청 총 빌 리루빈 수치가 남성과 여성 모두에서 대사증후군 위험과 역상 관 관계에 있다고 보고하였다. 유사하게 한국인 6,205명을 대 상으로 한 후향적 코호트 연구에서 높은 총 빌리루빈은 대사증 후군과 역상관 관계가 있음을 보여 주었다[18]. 대조적으로, 일 본 코호트 연구에 따르면 혈청 총 빌리루빈은 남성에서는 대사 
Table 5. Odds ratio for metabolic syndrome according to T-Bil, ALT and GGT quartile

\begin{tabular}{|c|c|c|c|c|}
\hline Men & 1st quartile & 2nd quartile & 3rd quartile & 4th quartile \\
\hline \multicolumn{5}{|l|}{ T-Bil (mg/dL) } \\
\hline No adjusted & 1 & $0.925(0.797 \sim 1.075)$ & $0.973(0.839 \sim 1.127)$ & $0.985(0.850 \sim 1.141)$ \\
\hline Model 1 & 1 & $0.935(0.805 \sim 1.087)$ & $0.896(0.851 \sim 1.144)$ & $0.983(0.848 \sim 1.140)$ \\
\hline \multicolumn{5}{|l|}{$\operatorname{ALT}(I U / L)$} \\
\hline No adjusted & 1 & $0.972(0.818 \sim 1.155)$ & $1.149(0.981 \sim 1.346)$ & $1.014(0.872 \sim 1.180)$ \\
\hline Model 1 & 1 & $0.984(0.827 \sim 1.170)$ & $1.161(0.990 \sim 1.361)$ & $1.016(0.873 \sim 1.184)$ \\
\hline \multicolumn{5}{|l|}{ GGT (IU/L) } \\
\hline No adjusted & 1 & $1.032(0.887 \sim 1.200)$ & $1.028(0.874 \sim 1.209)$ & $0.980(0.821 \sim 1.169)$ \\
\hline Model 1 & 1 & $1.033(0.887 \sim 1.203)$ & $1.026(0.872 \sim 1.207)$ & $0.973(0.815 \sim 1.162)$ \\
\hline Women & 1st quartile & 2nd quartile & 3rd quartile & 4th quartile \\
\hline \multicolumn{5}{|l|}{ T-Bil (mg/dL) } \\
\hline No adjusted & 1 & $0.785(0.620 \sim 0.994)$ & $0.832(0.663 \sim 1.043)$ & $0.809(0.647 \sim 1.011)$ \\
\hline Model 1 & 1 & $0.811(0.633 \sim 1.038)$ & $0.870(0.686 \sim 1.104)$ & $0.829(0.655 \sim 1.048)$ \\
\hline \multicolumn{5}{|l|}{ ALT (IU/L) } \\
\hline No adjusted & 1 & $1.015(0.769 \sim 1.340)$ & $1.041(1.094 \sim 1.796)$ & $1.078(0.844 \sim 1.375)$ \\
\hline Model 1 & 1 & $0.946(0.707 \sim 1.266)$ & $1.379(1.063 \sim 1.789)$ & $1.049(0.813 \sim 1.353)$ \\
\hline \multicolumn{5}{|l|}{ GGT (IU/L) } \\
\hline No adjusted & 1 & $0.921(0.723 \sim 1.174)$ & $1.055(0.820 \sim 1.358)$ & $0.871(0.657 \sim 1.155)$ \\
\hline Model 1 & 1 & $0.897(0.695 \sim 1.157)$ & $1.036(0.794 \sim 1.352)$ & $0.831(0.618 \sim 1.119)$ \\
\hline
\end{tabular}

Adjusted odds ratios for age.

Model 1 was adjusted for age.

Abbreviations: See Table 1.

증후군 위험과 역상관 관계를 보였지만, 여성에서는 관련이 없 는 것으로 밝혀졌다[19]. 또한 다른 일본 코호트 연구는 총 빌리루 빈과 대사증후군 사이의 유의한 연관성을 발견하지 못하였다[10].

본 연구에서 총 빌리루빈은 남녀 모두에서 복부비만, 중성지 방과 역상관 관계를 보였으며, $\mathrm{HDL}$-콜레스테롤과는 정적 상관 성을 나타냈다. 그러나 이러한 상관성은 ALT 및 GGT와 같은 간 특이적 효소보다 약한 상관성이었다. 또한 남녀 모두에서 대사 증후군 위험요인이 없는 군보다 대사증후군 진단군에서 간 효 소치가 높았으며, 총 빌리루빈과 직접 빌리루빈치는 낮게 나타 났다. 그러나 연구에 따라 이와 같은 불일치는 총 빌리루빈 수준 이 그 주요 원인일 수 있다. 일본인 코호트 연구에서는 총 빌루리 빈 농도 $1 \mathrm{mg} / \mathrm{dL}$ 미만인 대상자가 $75 \%$ 였으나, 한국인을 대상 으로 한 연구는 $50 \%$ 이상에서 총 빌리루빈 농도가 $1 \mathrm{mg} / \mathrm{dL}$ 보 다 높았다[10,18]. 본 연구에서는 $43 \%$ 의 대상자가 총 빌리루빈 농도 $1 \mathrm{mg} / \mathrm{dL}$ 이상으로 나타나 대부분이 기준범위에 속해 과소 평가 되었을 가능성이 있다고 생각된다. 이러한 관점에서 다양 한 농도의 빌리루빈치와 대사증후군 위험요인간의 관련성에 대 한 평가가 필요하다.

빌리루빈은 그 자체뿐 아니라 대사과정에 참여하는 효소에 의해 대사증후군 발병 기작에 영향을 미칠 수 있다[16]. 헴은 속 도제한효소(rate-limiting enzyme)인 헴 산화효소(heme oxygenase, $\mathrm{HO}$ )의 이화작용에 의해 빌리버딘과 일산화탄소
를 형성하고, 빌리버딘은 빌리버딘 환원효소(biliverdin reductase, BVR)에 의해 빌리루빈으로 전환된다[3, 16]. 그러므로 헴 산화효소 활성에 의해 빌리루빈은 조절되며, 헴 산화효소와 빌리루빈은 항염증 및 항산화 작용에 의해 대사증후군 활성을 억제하는 것으로 보고된다[3, $16,20,21]$. 이와 같은 관점에서 Huang 등[22]은 건강한 중년 비흡연 남성에서 빌리루빈이 대 사증후군을 예측하는 지표라고 보고하였다. 그러나 혈청 빌리 루빈과 대사증후군의 연관성에 대해서는 논란의 여지가 있다. Oda 등[10]은 혈청 빌리루빈이 대사증후군과 관련이 없으므로 혈청 빌리루빈의 감소가 대사증후군의 원인에 의한 것이 아니 라 대사증후군과 밀접한 산화 스트레스에 의한 것임을 보고하 였다.

본 연구에서는 흡연에 대한 조사가 이루어지지 않아 단순 비 교는 어려우나 남녀 모두에서 ALT와 GGT뿐만 아니라 총 빌리 루빈은 대사증후군 발생 가능성을 예측할 수 있는 지표는 아닌 것으로 나타나 Oda 등[10]의 결과를 지지한다. 따라서 높은 빌 리루빈 수치는 대사증후군의 원인 요인은 아닐 수 있지만, 대사 증후군 발병 위험이 높은 환자에서 빌루리빈 수치가 낮게 나타 날 수 있음을 확인하였다.

본 연구는 횡단면 연구로서 혈청 총 빌리루빈 수치와 대사증 후군간의 인과관계를 확인할 수 없었다. 특히 빌리루빈 농도는 헴 산화효소의 상승과 더불어 증가할 가능성이 있으므로 헴 산 
화효소의 유도와 함께 혈청 빌리루빈치의 상승이 대사증후군의 발병과 진행을 막는 잠재적인 요인이 될 수 있는지 전향적인 연 구가 필요하다. 또한 총 빌리루빈 수치는 평가한 반면, 직접 및 간접 빌리루빈은 평가에서 제외되었으며, 향후 간기능 장애가 있는 환자를 대상으로 연구를 진행할 필요성이 있겠다. 본 연구 는 당뇨병, 고혈압에 대한 약물치료 이외의 고지혈증이나 비만 에 의한 약물치료 및 다른 기본 질병의 영향을 명확하게 밝히지 못하였으며, 음주, 흡연, 운동과 같은 생활습관에 관한 데이터를 수집하였음에도 불구하고 정확성이 떨어져 분석에 포함하지 못 한 제한점이 있다.

결론적으로, 한국 성인남녀에서 혈청 총 빌리루빈은 대사증 후군 구성요소와 약한 역상관 관계를 보였으며, 총 빌리루빈은 대사증후군 발생 가능성을 예측하는 지표는 아닌 것으로 나타 났다.

\section{요 약}

빌리루빈은 내인성 항산화제로서 항염작용이 있으며, 고혈 압, 당뇨병, 대사증후군 및 인슐린 저항성과 역상관 관계에 있다 고 보고된다. 그러나간 특이적 지표와 비교하여 빌리루빈과 대 사증후군간의 관련성을 평가한 연구는 부족하다. 본 연구에서 는 건강검진을 실시한 한국 성인남녀를 대상으로 ALT, GGT와 비교하여 총 빌리루빈과 대사증후군 유병률 사이의 관련성을 조사하고자 하였다. 이 횡단면 연구에는 2015년 3월부터 2018 년 2월까지 경기도 소재 종합병원에서 건강검진을 실시한 20세 이상 성인남녀 22,568명이 포함되었다. American Heart Association/National Heart, Lung, and Blood Institute (AHA/NHLBI)의 지침에 따라 대사증후군을 진단하였다. 남녀 모두에서 대사증후군 위험요인이 없는 군보다 대사증후군 진단 군에서 간 효소치가 높았으며, 총 빌리루빈과 직접 빌리루빈치 는 낮게 나타났다. 남녀 모두에서 혈청 총 빌리루빈은 복부비만 $(r=-0.066$ vs $r=-0.055)$, 중성지방 $(r=-0.127$ vs $r=-0.136)$ 과 약한 역상관 관계를 보였으며, 이는 ALT와 GGT보다 약한 관 련성이었다. 또한 남녀 모두에서 ALT와 GGT뿐만 아니라 총 빌 리루빈은 대사증후군 발생 가능성을 예측하는 지표는 아닌 것 으로 나타났다.

\section{Acknowledgements: None Conflict of interest: None}

\section{REFERENCES}

1. Roberts CK, Sindhu KK. Oxidative stress and metabolic syndrome. Life Sci. 2009;84:705-712.

2. Grundy SM, Cleeman JI, Daniels SR, Donato KA, Eckel RH, Franklin BA, et al. Diagnosis and management of the metabolic syndrome: an American Heart Association/National Heart, Lung, and Blood Institute Scientific Statement. Circulation. 2005;112:2735-2752.

3. Schwertner HA, Vítek L. Gilbert syndrome, UGT1A1*28 allele, and cardiovascular disease risk: possible protective effects and therapeutic applications of bilirubin. Atherosclerosis. 2008; 198:1-11.

4. Erdogan D, Gullu H, Yildirim E, Tok D, Kirbas I, Ciftci O, et al. Low serum bilirubin levels are independently and inversely related to impaired flow-mediated vasodilation and increased carotid intima-media thickness in both men and women. Atherosclerosis. 2006;184:431-437.

5. Perlstein TS, Pande RL, Beckman JA, Creager MA. Serum total bilirubin level and prevalent lower-extremity peripheral arterial disease: National Health and Nutrition Examination Survey (NHANES) 1999 to 2004. Arterioscler Thromb Vasc Biol. 2008; 28:166-172.

6. Perlstein TS, Pande RL, Creager MA, Weuve J, Beckman JA. Serum total bilirubin level, prevalent stroke, and stroke outcomes: NHANES 1999-2004. Am J Med. 2008;121:781-788.

7. Li M, Kim DH, Tsenovoy PL, Peterson SJ, Rezzani R, Rodella LF, et al. Treatment of obese diabetic mice with a heme oxygenase inducer reduces visceral and subcutaneous adiposity, increases adiponectin levels, and improves insulin sensitivity and glucose tolerance. Diabetes. 2008;57:1526-1535.

8. Jo J, Yun JE, Lee H, Kim H, Jee SH. Total, direct, and indirect serum bilirubin concentrations and metabolic syndrome among the Korean population. Endocrine. 2011;39:182-189.

9. Li XH, Lin HY, Guan LY, Peng H, Wen MM, Cao YQ, et al. Direct bilirubin levels and risk of metabolic syndrome in healthy Chinese men. Biomed Res Int. 2017;2017:9621615.

10. Oda E, Aizawa Y. Total bilirubin is inversely associated with metabolic syndrome but not a risk factor for metabolic syndrome in Japanese men and women. Acta Diabetol. 2013;50: 417-422.

11. Perera S, Lohsoonthorn V, Jiamjarasrangsi W, Lertmaharit S, Williams MA. Association between elevated liver enzymes and metabolic syndrome among Thai adults. Diabetes Metab Syndr. 2008;2:171-178.

12. Shin KA. The clinical implications of hepatic enzymes in metabolically healthy obese men. Korean J Clin Lab Sci. 2017; 49:248-255.

13. Grundy SM, Cleeman JI, Daniels SR, Donato KA, Eckel RH, Franklin BA, et al. Diagnosis and management of the metabolic syndrome: an American Heart Association/National Heart, Lung, and Blood Institute Scientific Statement. Circulation. 2005;112: 2735-2752.

14. World Health Organization. The Asia-Pacific Perspective: Redefining obesity and its treatment. Sydney, Australia: health communications Australia; 2000. p19-20.

15. Wu TW, Fung KP, Wu J, Yang CC, Weisel RD. Antioxidation of 
human low density lipoprotein by unconjugated and conjugated bilirubins. Biochem Pharmacol. 1996;51:859-862.

16. Guzek M, Jakubowski Z, Bandosz P, Wyrzykowski B, Smoczyński M, Jabloiska A, et al. Inverse association of serum bilirubin with metabolic syndrome and insulin resistance in Polish population. Przegl Epidemiol. 2012;66:495-501.

17. Wu Y, Li M, Xu M, Bi Y, Li X, Chen Y, et al. Low serum total bilirubin concentrations are associated with increased prevalence of metabolic syndrome in Chinese. J Diabetes. 2011;3:217-224.

18. Lee MJ, Jung CH, Kang YM, Hwang JY, Jang JE, Leem J, et al. Serum bilirubin as a predictor of incident metabolic syndrome: a 4-year retrospective longitudinal study of 6205 initially healthy Korean men. Diabetes Metab. 2014;40:305-309.

19. Ishizaka N, Ishizaka $\mathrm{Y}$, Toda E, Nagai R, Yamakado M.
Association between serum uric acid, metabolic syndrome, and carotid atherosclerosis in Japanese individuals. Arterioscler Thromb Vasc Biol. 2005;25:1038-1044.

20. Lin JP, Vitek L, Schwertner HA. Serum bilirubin and genes controlling bilirubin concentrations as biomarkers for cardiovascular disease. Clin Chem. 2010;56:1535-1543.

21. Kappas A. A method for interdicting the development of severe jaundice in newborns by inhibiting the production of bilirubin. Pediatrics. 2004;113:119-123.

22. Huang SS, Chan WL, Leu HB, Huang PH, Lin SJ, Chen JW. Serum bilirubin levels predict future development of metabolic syndrome in healthy middle-aged nonsmoking men. Am J Med. 2015;128:1138. 